\title{
Lessons from Post-colonial Malaysian Economic Development
}

\author{
Jomo K. S. ${ }^{1}$ with Wee Chong Hui ${ }^{2}$
}

September 2010

\begin{abstract}
Malaysian economic development has been shaped by public policy in response to changing national and external conditions. Public investments peaked in the 1970s and early 1980s, until the policy reversals driven by sovereign debt concerns and new policy ideology fads. Foreign investments continued to be favoured after independence for ethnic political reasons. Thus, foreign investments continued to be very significant in financial services as well as manufacturing growth, both for import substitution from the 1960s and for export from the 1970s. Private investments were attracted by government provision of infrastructure, cheap but schooled labour, tax incentives, lax environmental regulations and an undervalued currency. Poverty reduction and ownership redistribution by ethnicity were most successful during the 1970s and early 1980s, although it is unclear how much these improved inter-ethnic relations. Economic liberalization and the growing influence of business interests and political elites have undermined the government's developmental role, culminating in the 1997-8 financial crisis and lacklustre growth since. Malaysian industrialization could only have been achieved with appropriate incentives for investments and technical progress through key policy interventions.
\end{abstract}

Keywords: Malaysia, development strategies, liberalization, intervention

JEL classification: O16, O2

Copyright (C) UNU-WIDER 2010

${ }^{1}$ UN-DESA, ${ }^{2}$ Universiti Teknologi MARA Sarawak, Malaysia, email: chonghuiwee@yahoo.com

This study has been prepared within the UNU-WIDER project on Country Role Models for Development Success, directed by Augustin Kwasi Fosu.

UNU-WIDER gratefully acknowledges the financial contributions to the project by the Finnish Ministry for Foreign Affairs, and the financial contributions to the research programme by the governments of Denmark (Royal Ministry of Foreign Affairs), Finland (Finnish Ministry for Foreign Affairs), Sweden (Swedish International Development Cooperation Agency—Sida) and the United Kingdom (Department for International Development-DFID). 
The World Institute for Development Economics Research (WIDER) was established by the United Nations University (UNU) as its first research and training centre and started work in Helsinki, Finland in 1985. The Institute undertakes applied research and policy analysis on structural changes affecting the developing and transitional economies, provides a forum for the advocacy of policies leading to robust, equitable and environmentally sustainable growth, and promotes capacity strengthening and training in the field of economic and social policy making. Work is carried out by staff researchers and visiting scholars in Helsinki and through networks of collaborating scholars and institutions around the world.

www.wider.unu.edu

publications@wider.unu.edu

UNU World Institute for Development Economics Research (UNU-WIDER)

Katajanokanlaituri 6 B, 00160 Helsinki, Finland

Typescript prepared by Lisa Winkler at UNU-WIDER

The views expressed in this publication are those of the author(s). Publication does not imply endorsement by the Institute or the United Nations University, nor by the programme/project sponsors, of any of the views expressed. 


\section{Introduction}

This paper offers a review of Malaysia's economic growth and structural change over the half century since Malaya (later Peninsular Malaysia) gained independence in 1957 and Malaysia was formed six years later in 1963. At least five regimes with different priorities can be distinguished in Malaysian economic development from 1957 to the end of the Mahathir era in late 2003. The economic role of government, particularly in terms of public finance and public spending, is found to have played an important part in shaping the generally impressive record of post-colonial economic development in Malaysia. This should make clear that Malaysia's generally impressive post-colonial economic development has been largely due to appropriate government interventions and reforms, rather than a simple reliance on market forces, as often suggested in some of the literature on the country.

During the colonial period, authority over plan formulation and implementation rested with senior British officials mainly concerned with imperial interests and committed to protecting the predominantly British plantation and mining interests in Malaya. Colonial bias for these interests was reflected in public development expenditure that prioritized economic infrastructure to service the primary commodity export economy. As Britain's most profitable colony, Malaya provided much of the export earnings that financed British post-war reconstruction. Legal developments during this era played an important role in shaping and developing British Malaya. During the early and mid-1950s, the colonial government initiated reforms, including rural development and affirmative action efforts in education that further boosted output and productivity.

Independence in 1957 was followed by a dozen of years of post-colonial economic diversification with limited government intervention. Generally, laissez-faire policies were pursued, with some import substituting industrialization, agricultural diversification, rural development and ethnic affirmative action efforts. A period of growing state intervention followed the post-election race riots of May 1969. The New Economic Policy (NEP) legitimized increasing government intervention and public sector expansion for inter-ethnic redistribution and rural development to reduce poverty. Export-oriented industrialization also generated considerable employment, especially for women, while increased petroleum revenues financed rapidly growing state spending.

Expansionary public expenditure from the 1970s continued after Mahathir became Prime Minister in mid-1981. However, spending was cut from mid-1982, but government-sponsored heavy industries grew as other foreign investments declined. Thus, state intervention under Mahathir shifted from inter-ethnic redistribution to heavy industrialization. From the mid-1980s, the economic slowdown and massive foreign debt build-up from the early 1980s led to massive ringgit depreciation and economic liberalization accompanied by privatization and greater government support for the private sector, including new investment incentives and regressive tax reforms. The new measures favouring private investment resulted in a decade of rapid growth until the 1997-8 financial crisis led to renewed state intervention for crisis management and economic recovery, including currency controls and bail out facilities for the banking sector and some favoured corporate interests. 


\section{The Alliance phase (1957-69)}

In preparing for political independence, the British ensured that the leftist anti-colonial forces who threatened their economic interests were curbed, while ethnic elites committed to protecting interests were groomed to eventually inherit state office to ensure continuity in economic policy-making. With attaining independence in August 1957, the Alliance - a coalition of the political elites from the three major ethnic groups-formally took over political authority in Malaya. Not unlike other newly independent countries, the post-colonial government embarked upon a programme of economic development emphasizing economic diversification. The post-colonial government continued to promote private enterprise and encourage foreign investment inflows, while the economic interests of the ex-colonial power were protected.

The Alliance government's economic development strategy reflected the class interests represented by the major parties in the ruling coalition and the political compromise among their leaders and with the colonial power. Consistent with this compromise, the state pursued basically laissez-faire policies with minimal state interference-and small budget deficits - except in ensuring attractive conditions for new investments. The post-colonial government was committed to defending British business interests in Malaya, which also enabled the predominantly Chinese local businesses to consolidate and strengthen their position. Development policy during this phase was therefore influenced by these compromises. The essentially laissez-faire approach precluded direct government participation in profitable activities, which were left to the private sector. Hence, a relatively low proportion of public development expenditure was allocated to commerce and industry. Within this overall strategy, the government made some highly publicized, but nonetheless feeble attempts to promote the interests of the nascent Malay business community, while also undertaking rural development programmes to secure predominantly Malay rural electoral support.

Increased allocations for social services, particularly education, reflected the increased commitment to utilize educational expenditure to create a Malay middle class besides meeting the human resource requirements of the rapidly growing and modernizing Malaysian economy. Government agricultural development policies were essentially conservative. Rural development efforts were constrained by the government's reluctance to act against politically influential landed, commercial and financial interests. The main thrust of rural development efforts involved new land development by the Federal Land Development Authority (FELDA), other measures to increase agricultural productivity and rural incomes, as well as greater provision of rural facilities such as roads, schools, clinics, irrigation etc.

During the early years after independence, the major physical development initiatives in the country were reflected in the annual budgets and the five-year Malaysia Plans. Almost all the infrastructure developments undertaken before the late 1980s were financed by the government, averaging about a third of overall public expenditure. Private sector involvement in infrastructure was largely for construction and did not involve much financing or revenue collection by the government from such developments.

Development policy in the 1960s emphasized growth, assuming that its benefits would trickle down. Malaysia achieved impressive growth, with considerable infrastructure development, although economic diversification in both agriculture and industry was 
limited despite efforts to reduce Malaya's overreliance on tin and rubber on two main fronts. First, plantations were encouraged to grow other crops, particularly oil palm, with an increasing number of FELDA-sponsored land development schemes also planted with oil palm. Second, the state encouraged manufacturing by offering incentives, and providing infrastructure and other supportive economic measures.

The government promoted moderate import substituting industrialization, passing the Pioneer Industries Ordinance and creating facilitative institutions. However, due to the limited size of the domestic market, limited domestic linkages, growing unemployment and other problems, the government gradually shifted to export-oriented industrialization from the late 1960s. The Federal Industrial Development Authoritynow the Malaysian Industrial Development Authority, or MIDA—was established to encourage industrial investment and the Industrial Incentives Act of 1968 was enacted, offering incentives to attract more labour-intensive export-oriented industries.

Helped by favourable commodity prices and some early success in import substituting industrialization, the Malayan, and then Malaysian, economy sustained high growth with low inflation in the 1960s. At the time of independence and even in the late 1960s, the private sector was largely confined to local Chinese capitalists and the generally more powerful foreign investors. While the Chinese were mainly in retail and wholesale trade, rubber estates, tin mining, domestic transport, small-scale manufacturing and some banking, foreign interests dominated the formal economy, such as the large plantations, trading agencies, tin dredge mines, bigger banks and financial institutions (e.g. insurance), and manufacturing. Malay business interests were generally encouraged by the government through Bumiputera trust agencies and the state economic development corporations (SEDCs), with a few well-connected individuals spread over many boards desiring them for their political connections (Tan 1982).

Official statistics suggest a worsening income distribution over the 1960s, including a growing gap between rural and urban areas. Inequality within the Malay community increased most among all major ethnic groups - from least intra-ethnic inequality in 1957 to greatest inequality in 1970. However, this growing inequality did not only result in increased class tensions, but was primarily perceived in racial terms, not least because of widespread political mobilization along ethnic lines. Hence, Malay resentment to domination by capital was primarily expressed against ethnic Chinese, who comprised the bulk of businessmen, while non-Malay frustrations were directed against the Malay-dominated post-colonial state, widely identified with the United Malays National Organisation (UMNO), the dominant partner in the ruling coalition. This led to racially-inspired opposition to the ruling coalition of ethnic parties in the Alliance in the 1960s, culminating in the 'race riots' of May 1969. Import substituting industrialization through tariff protection had generated relatively little employment and petered out by the mid-1960s, while rural development efforts emphasizing productivity avoided redistribution in favour of the poorly capitalized, land-hungry peasantry. At the May 1969 general elections, the ruling coalition's grip on power was significantly challenged by non-Malay as well as Malay-based opposition parties. Following the elections, the incumbent Prime Minister's position was undermined by his critics within the ruling party, who supported his deputy after ethnic riots-probably initiated by the youth wing of the ruling party, led by a State Chief Minister whose own position was threatened by the election results. 
The poor electoral performance of the ruling coalition was probably the result of ethnic political mobilization, continued economic deprivation, growing unemployment, and inter-ethnic disparities despite respectable economic growth. The general election results and 'race riots' of May 1969 thus reflected some ethnic dimensions of the new post-colonial socioeconomic order. Meanwhile, the emerging Malay middle class, who had nominal political control, feared the gradual decline of British economic hegemony would lead to Chinese ascendance. This 'political-bureaucratic' faction, which had become more assertive from the mid-1960s, succeeded in establishing greater dominance after May 1969.

\section{The first decade of the New Economic Policy (1970-80)}

Announced in 1970 by Razak Hussein, then Deputy Prime Minister and Director of the National Operations Council, set up during the state of emergency after the events of May 1969, the New Economic Policy (NEP) sought to create the socioeconomic conditions for 'national unity' through massive economic redistribution programmes to achieve its twin prongs of 'poverty eradication' and 'restructuring of society'. The NEP's first Outline Perspective Plan for 1971-90 (OPP1) envisaged the incidence of poverty declining from 49 per cent in Peninsular Malaysia in 1970 to 16.7 per cent in 1990. Meanwhile, 'restructuring society' efforts sought to reduce inter-ethnic economic disparities, to 'eliminate the identification of race with economic function'. OPP1 envisaged raising the Bumiputera share of corporate equity from 2.5 per cent in 1970 to 30 per cent in 1990, ostensibly through growth, rather than redistribution of existing wealth. Through ethnically differentiated financing of, and controlled access to tertiary level education, the NEP would reduce inter-ethnic disparities in the professions and other lucrative occupations.

Affirmative action programmes (for Bumiputera indigenes, especially Malays) from the early 1950s, which increased after independence and especially from the mid-1960s, had included preferential access to educational opportunities, business licences, as well as employment and promotion, especially in the public sector with the Malayanization of the civil service after independence. Greater Malay political hegemony after the events of May 1969 significantly enhanced such measures. Government intervention in the economy grew, and the number of state-owned enterprises (SOEs) increased during the 1970s, ostensibly for the primary purpose of NEP-type redistribution.

To raise the total Bumiputera share of corporate equity to 30 per cent by 1990 from 2.4 per cent in 1970, the government began to find new ways and means to increase equity held by Bumiputera trust agencies as well as individuals. Educational spending significantly increased to finance a significant expansion of Bumiputera secondary and tertiary education, especially with the preferential allocation of scholarships to attend universities in Malaysia and abroad. Bumiputera have also been favoured for employment and promotion opportunities, not only in the government and state-owned enterprises, but also in the private sector, especially enterprises requiring government approval of some kind or other.

Political and bureaucratic control over planning expanded in the 1970s-with greater state intervention and a considerably larger public sector, particularly to promote the growth of the Malay capitalist and middle classes. New legislation and institutions were set up for this purpose, often in the form of public enterprises, such as statutory bodies 
enacted by legal statute. Examples of these include the Urban Development Authority (UDA), Pernas (Perbadanan Nasional Berhad), and the SEDCs. The other increasingly widespread form of public enterprise was government-owned (private or public limited) companies (Jomo 1995). Development policy in the 1970s thus saw greater state intervention in public resource allocation as well as public sector ownership and control of business enterprises. Though such policies began to adversely affect private investments and encourage capital flight, especially by ethnic Chinese, this was more than offset by growing public investments as well as foreign direct investment (FDI) in export-oriented industries.

Export-oriented manufacturing in Malaysia in the 1970s was largely limited to the relatively low skill, labour-intensive aspects of production, especially electronic component assembly. Though more skilled and complex production processes and training have developed since, Malaysia has lagged further behind neighbouring Singapore. The likelihood of such progress has been determined by the interests and preferences of transnational corporations as well as host government policies. Exportoriented industrialization has significant, but nonetheless limited potential for sustained and integrated industrial development, especially because of the technological and market dependence involved. Despite impressive performance, largely attributable to favourable resource endowments and external conditions and exaggerated by the high import content of non-resource based manufactured exports, export-led growth in the Malaysian economy is not sustainable indefinitely. The very success of export-led growth has probably discouraged more serious efforts to develop a more balanced and integrated national economy.

Although the government attempted to portray itself as a neutral arbiter mediating between capital and labour in the 1960s and 1970s, it prioritized investment promotion, as reflected in various amendments to the labour laws. During the state of emergency after May 1969, labour legislation was amended to limit trade union organization and activity and to allow women to work around the clock, as desired by some of the new (mainly electronic) industries. Post-colonial labour legislation had been initially enacted to replace the special regulations introduced during the states of emergency against the communist-led insurgency (1948-60), but later reflected the changing labour policies of the post-colonial government.

The promotion of more labour-intensive, export-oriented industries from the late 1960s succeeded in reducing unemployment, initially at the expense of real wages, until lower unemployment pushed wages up once again from the mid-1970s onwards. The Free Trade Zones Act in the early 1970s created new customs-free export-processing zones. After further 'tightening' labour laws in 1980, the industrial relations machinery and labour policies also changed, largely at the expense of employees and unions. Later, more amendments were introduced to tighten up the already restrictive labour laws, further limiting union rights, encouraging 'in-house' or company unions and increasing government control over employees, who comprised an increasing majority of the labour force.

In the mid-1970s, petroleum production off the East Coast of Peninsular Malaysia began, and the government pushed through the 1974 Petroleum Development Act to ensure that the federal government-instead of the states-would capture the lion's share of oil revenues. Petroleum revenue has played a crucial role in the country's 
development since; they have been used to bail out government-owned enterprises and to finance prestige projects.

Relatively high economic growth, coupled with the expansion of labour-intensive, export-oriented industries and the public sector in the 1970s, led to declining unemployment through the decade. Also, emigration of Malaysian labour to Singapore and other countries increased in the mid- and late 1970s. Consequently, real wages rose and pockets of labour shortages emerged, usually in activities offering low wages and poor working conditions as well as future prospects. In order to offset the upward pressure on wages and to overcome labour shortages, the government adopted several measures, most notably by allowing labour immigration, primarily from Indonesia, Southern Thailand, Southern Philippines and later Bangladesh. While the magnitude of this immigration since the 1980s is difficult to measure, current estimates vary from 1.5 to 4 million compared to a national population of 26 million and a labour force of over 12 million.

\subsection{Mahathir's three regimes}

In mid-1981, Mahathir Mohamad took over as Prime Minister of Malaysia when the world economy slowed down, lowering primary commodity prices, and Malaysia increased foreign borrowings despite much higher real interest rates from 1980. The increase in public expenditure in the early 1980s was originally counter-cyclical in intent, to compensate for declining private investment, both domestic and foreign. Under Mahathir's leadership, public sector spending rose sharply-even after such counter-cyclical spending was cut back from mid-1982 onwards-to finance nonfinancial public enterprises (NFPEs) in the first half of the 1980s. External debt more than tripled from 1980 to 1985, largely in the form of government-guaranteed external debt by the NFPEs.

More than any other prime minister of Malaysia, Mahathir wanted to transform Malaysia into a newly industrializing country under indigenous Bumiputera corporate leadership. While Mahathir's policies eventually favoured various well-connected business interests, he has to be credited with the major development policy innovations from 1981 until his retirement in late 2003, including the 'Look East' policy, his labour policy, the 'Malaysia Incorporated' policy, the privatization policy, 'Vision 2020', and the policy responses to the 1997-8 crisis, among others. Three distinguishable economic policy regimes characterized the Mahathir administration.

\subsubsection{Mahathir regime 1: new roles for the state (1981-5)}

After taking over as Prime Minister, Mahathir introduced a second round of import substitution to promote various heavy industries, similar to the heavy and chemicals industrialization drive in South Korea under General Park Chung Hee in the 1970s. He initially continued to increase public sector employment in the face of global recession from the early 1980s onward. As the world economic slowdown dragged on and commodity prices continued to decline, continued economic growth became more dependent on public-rather than private-investment. The new Mahathir administration also hoped to secure a strong electoral mandate through such deficit spending. Soon after winning the April 1982 general elections, the government announced an austerity drive, cutting back public spending and reducing earlier job creation commitments. 
The rapid increase in domestic public debt from the early 1970s was followed by some rise in sovereign foreign borrowings in the early 1980s as the current account deficit grew because of declining commodity export prices and weaker demand for manufactured exports (especially electronics), as private investments outside the oil and gas sector dropped sharply (World Bank 1983). Domestic private investments also continued to decline, largely due to capital flight associated with official ethnic discrimination against Chinese business interests. Malaysia did not experience many of the painful economic problems other less fortunate economies of the South had experienced in the 1980s. For instance, Malaysia never really suffered from capital shortages, and did not borrow heavily from abroad until the early 1980s-ironically, when liquidity was tighter and real interest rates higher. However, its borrowing binge soon came to an end in the mid-1980s.

Malaysia's mild economic recession during the mid-1980s was due to a combination of factors: global recession, lower primary commodity prices, reduced demand for manufactured exports, reduced foreign private investment inflows, declining domestic private investments, deflationary fiscal and monetary policies (except for certain spending priorities such as heavy industries), concentration of public investments in import substituting heavy industries characterized by low capital productivity, tighter international liquidity and higher real interest rates. Immediately, the government responded to the recession with various measures, such as deregulation as well as incentives to further encourage private investment.

Spending was constrained by the sharp drop in oil prices in early 1986 to under US\$10 per barrel. The poor price outlook for petroleum forced a drastic downward revision of growth and public sector investment targets (later revised upwards with higher petroleum and rubber prices in 1987 and increased logging). The major primary commodity price collapses - involving palm oil, tin and petroleum-and the electronics business cycle's low point occurred in 1985. Meanwhile, land and regional development authorities continued to clear forested areas for plantation agriculture, increasingly in Sabah and Sarawak. Agricultural diversification continued, with cocoa promising to be the new hope in Sabah in the 1980s, while oil palm's success from the 1970s continued in most other parts of the country (Jomo, Chang, Khoo with others 2004).

Malaysia's resource wealth and relatively cheap labour have sustained production enclaves for the export of agricultural, forest, mineral and manufactured products. Much of the retained wealth generated has been captured by the business cronies of those in power, who have contributed to growth by reinvesting the captured rents, mainly in the 'protected' domestic economy, e.g. in import substituting industries, commerce, services and privatized utilities and infrastructure.

\subsubsection{Mahathir regime 2: inducing private investments (1986-1997)}

By the mid-1980s, there was growing dissatisfaction with the government among many, including Bumiputeras, both in the public and private sectors, with some criticizing what they considered government interference unfair in the business world. Large Malay-controlled business groups had emerged on the corporate scene and were calling for a less regulated economy. Indeed, some of them blamed excessive state intervention for slowing economic growth and undermining private business interests. Partial deregulation of the economy was probably a boon to the corporate sector, with most businesses benefiting, and hence supportive of further liberalization. 
The key turning point for government policy, in terms of economic liberalization, occurred around 1985, following Daim Zainuddin's appointment as Finance Minister in 1984. The government introduced some economic liberalization measures, which coincided with the contraction of loss-making SOEs. These had grown in the 1960s and expanded rapidly in the 1970s (under the NEP), with new ones continuing to grow in the early 1980s as others began contracting. SOE losses wasted precious investment resources, increased the government's financial burden and allegedly slowed economic growth. Privatization, officially announced in 1983, gained vigour and the government actively began privatizing its assets until there were some 200 privatization projects in the pipeline by the mid-1990s. Privatization was supposed to reduce government expenditure, improve efficiency, encourage private sector involvement in government activities, and provide Bumiputeras with more opportunities to participate in such activities.

The government also sought to attract new, especially foreign investments, with the 1986 Promotion of Investments Act (Jomo 2007b; Jomo with Wong 2008). The timing was perfect, as manufacturers from Northeast Asia (especially Japan and later Taiwan) relocated their industries to take advantage of the enhanced incentives, relatively good infrastructure and more lax environmental and other regulations, as well as comparatively lower production costs due to the lower wages and devalued exchange rates.

The 1988 withdrawal of privileges under the General System of Preferences from the first-tier East Asian new industrialized economies (NIEs) also encouraged relocation of production facilities abroad. Meanwhile, reforms, selective deregulation as well as new rules and incentives made relocation in Southeast Asia as well as China more attractive. Malaysia greatly benefited from investments from these East Asian economies experiencing rising production costs (due to tighter labour markets), strengthened intellectual property rights as well as stricter environmental regulations. From late 1985 onwards, the Japanese yen and then the Korean won, the new Taiwanese dollar and the Singapore dollar appreciated against the US dollar, and hence even more against the ringgit, enhancing Malaysia's attractiveness to foreign investors, particularly those from East Asia.

After the government introduced new liberalizing economic policy reforms, business sentiment improved. In addition, new investments poured in from more developed countries in East Asia, notably Japan, Singapore and later Taiwan, Province of China. As the government policy reform efforts not only benefited foreign investors, but were also seen as encouraging non-Malay investors, domestic firms became more supportive of policy reforms. Politically influential corporate groups developed various means to better advance their interests, while appreciating the greater freedom and flexibility, as well as reduced tax burdens and regulations.

Initially driven by East Asian export-oriented manufacturing investments, the Malaysian economy recovered significantly from 1987, and maintained growth rates of over 8 per cent per annum for a decade from 1988 onwards. Thus, the policy changes of the mid1980s appeared successful in reviving growth and industrialization. The time sequence has encouraged the attribution of the economic boom to the policy changes. However, as the preceding account suggests, while several developments occurring at the same time may all have contributed to the recovery, it is difficult to disaggregate their respective contributions. Growth in Singapore, Thailand and Indonesia seems to have 
accelerated in the late 1980s as well, and although most of these countries also introduced some economic liberalization measures around the same time, there is no evidence that the most successful or fastest growing have been the most liberalized economies, or even that trade or financial liberalization measures-as opposed to specific investment incentives - contributed crucially to the boom.

In 1990, the twenty-year period (1971-90) of the first OPP1 for Malaysia's NEP came to an end. The ambitious NEP redistribution targets had been largely achieved by then, with most progress made before the mid-1980s. Despite some controversy over the reliability and comparability of official data, the reduction in the incidence of poverty according to official indicators was impressive, declining from 49 per cent in 1970 to 17.1 per cent in 1990 , very close to the 16.7 per cent target.

Inter-ethnic economic disparities of various types had also declined significantly, e.g. the gaps among mean household incomes by ethnicity narrowed. Ethnic proportions in economic activities and occupations increasingly reflected demographic shares except in agriculture and government services (which remained predominantly Bumiputera) and in wholesale and retail trade (which remained Chinese-dominated). For eight well-remunerated professions, the Bumiputera share rose from 6 per cent in 1970 to 25 per cent in 1990, with continued ongoing increases in the Bumiputera share. Through government regulation of business opportunities and investments as well as preferential policies for Bumiputera businesses, the Bumiputera share of equity in public listed companies rose from 1.5 per cent in 1969 to 18 per cent in 1983, before hovering around 20 per cent since then. Meanwhile, various observers have claimed considerable official underestimation of the actual size of the Bumiputera share of corporate wealth.

Yet, despite considerable achievement of the OPP1 targets, it is far from clear how much progress had been made in achieving 'national unity', the NEP's ostensible purpose, e.g. as reflected in reduced inter-ethnic resentment or improved inter-ethnic relations. For example, relations between Malays and Chinese were, arguably, rather tense in 1987 due to the political machinations of certain political leaders. However, with some cultural and educational deregulations from the mid-1980s and the economic boom of the 1990s, ethnic tensions seemed to recede somewhat. Meanwhile, regional grievances - especially in Sabah and Sarawak-became more pronounced, while ethnic minorities-both non-Malay Bumiputeras and non-Chinese non-Bumiputeras-became more alienated.

With the 1991 enunciation of Vision 2020 to achieve growth, modernization and industrialization, instead of the NEP's emphasis on inter-ethnic redistribution, foreign investors continued to be courted. The government also further reduced restrictions on ethnic Chinese capital, which had been encouraged by various other reforms, e.g. easier listing on the stock market, greater official encouragement of small and medium industries, other official efforts mitigating the 1975 Industrial Co-ordination Act as well as greater overall emphasis on the market, rather than regulatory measures. Hence, domestic investments were encouraged by the partial liberalization from the mid-1980s onwards. As many Chinese-owned firms were able to obtain stock market listing, they could tap into the domestic capital market for funds. However, it remains unclear whether public listing has been primarily intended to raise capital or to enable the owners to 'cash out'. 
In the early and mid-1990s, official policy encouraged Malaysian firms (especially large corporations) to invest in other developing countries in Southeast Asia, as well as Africa, South Pacific, the central Asian former Soviet republics, and even Europe and the US (Jomo 2002). The Malaysian South-South Corporation Berhad (Masscorp) was formed to help large Malaysian firms invest elsewhere in the 'South'. The government helped such firms by setting up agencies to facilitate trade, export credit and insurance, signing double taxation agreements with various countries, and organizing numerous trade and investment missions led by government ministers. However, this policy was suspended following the 1997-8 crisis in an attempt to revive domestic investments.

Over the years, the government has changed its industrialization strategy. In response to problems and new priorities, the government announced the Second Industrial Master Plan for 1996-2005 in December 1996 to replace the (first) Industrial Master Plan for 1986-95. In September 1996, the government had set up the Multimedia Super Corridor to promote certain information technology investments. The government committed over RM50 billion for infrastructure development to support this initiative. At the same time, the government strengthened intellectual property laws to reassure foreign investors and provided more generous incentives for new investments in this area.

Thus, the policy changes of the mid-1980s appeared successful in reviving growth and industrialization. Confirmation of the new policy direction from the mid-1980s came with the 1991 enunciation of Vision 2020, favouring growth, modernization and industrialization. Although FDI began levelling off in the mid-1990s, increased domestic investments - inspired by greater domestic investor confidence-sustained the momentum of rapid economic growth until the 1997-8 regional crisis. The gravity of the crisis and the difficulties of recovery were exacerbated by injudicious policy responses, compromised by cronyism, though there is little persuasive evidence that cronyism itself precipitated the crisis.

\subsubsection{Mahathir regime 3: crisis management, 1997-2003}

The 1997-8 East Asian economic crises began as currency crises following deregulation and other developments associated with financial liberalization and globalization, i.e. the subversion of effective financial governance at both international and national levels (Jomo 2004, 2007a; Wong and Jomo with Chin 2005). Crony capitalism and rentseeking had also been rife, but did not precipitate and cannot explain the crisis. However, cronyism, nepotism and new crisis-induced political developments compromised official policy responses as the crisis unfolded. With confidence undermined, the crisis worsened, further delaying recovery. The currency and financial crises thus became a crisis of the 'real economy' in Malaysia mainly due to poor government policy responses.

Despite the official claim that the ringgit was pegged to a 'basket of the currencies of Malaysia's main trading partners', it was virtually pegged to the US dollar for decades from the mid-1970s, albeit at different rates. This offered certain advantages, especially exchange rate stability. Low inflation was desired by the politically influential financial sector. Such priorities reflected the weaker influence of export manufacturers in Malaysia on economic policy-making (where much industrial capability outside of ethnic Chinese dominated resource-based manufacturing is foreign-owned), compared to the financial community. 
Meanwhile, equity finance grew in significance from the 1980s onwards in Malaysia. Domestic financial sector reforms had also reduced the powers and jurisdiction of the central bank. Not surprisingly, bank intermediation declined in overall importance and contributed proportionately less to financing productive investments. In spite of deregulation measures, government controls on the economy have not disappeared. For instance, in the banking sector, the central bank still guides liberalization of the industry, having forced local banks to merge, ostensibly to give them a better chance of survival as the industry opens up to foreign participation. Meanwhile, foreign banks already in Malaysia have been repositioning themselves to take advantage of the new opportunities with the changing policy and regulatory environment as the government prepares to open up the country's banking system to other foreign banks. The Securities Commission, set up to regulate the equities market, has put new regulations in place. Unfortunately, few such reforms have prioritized the governance requirements of new development challenges, but have instead been principally concerned with market developments and political pressures.

Capital inflows - into the stock market as well as through bank borrowings-helped finance current account deficits due to the growing proportion of 'non-tradables' produced in Malaysia, mainly related to construction. These inflows were 'sterilized' to minimize consumer price inflation, as desired by the financial community, but instead fuelled asset price inflation, mainly involving real estate and share prices. Following the mid-1995 reversal of the decade-long yen appreciation, the over-valued ringgit and other regional currencies plus the new financial investment opportunities, following partial financial liberalization, created the conditions for the asset price inflationary bubbles that later burst with devastating consequences for the region.

The Malaysian crisis was exacerbated by poor policy responses. Crony capitalism and rent-seeking had been rife, but did not precipitate and cannot explain the crisis. However, cronyism, nepotism and new crisis-induced political developments undoubtedly compromised official policy responses as the crisis unfolded. Confidence in the government was thus further undermined, which exacerbated the crisis, and thus delayed recovery. The currency and financial crisis thus became a crisis of the 'real economy’ in Malaysia mainly due to poor government policy responses.

The currency and financial crises suggest that Malaysia's decade-long economic boom until 1997 was built on some fragile and unsustainable foundations. Meanwhile, limited and inappropriate public investments have held back the development of greater industrial and technological capabilities. Although Malaysia has been reliant on foreign resources, especially immigrant labour, future economic progress cannot be secured by relying on cheap labour alone. With less than full employment as well as slower investment and productivity growth, private investment as a share of gross national product has been lower since the 1997-8 crisis.

\section{Lessons from the Malaysian experience}

The preceding review suggests that Malaysia has gone through several different development strategies in the 50 years since attaining independence, broadly identifiable with the four different prime ministers before current premier Abdullah Badawi took office in late 2003. However, despite some important differences between them, the second and third premiers are considered together here while three distinct phases are identified with Mahathir's 22 year tenure. Malaysian economic development 
policy has thus been primarily shaped by the nature of the regimes the dominant interests represented, and their respective views of what would be desirable to advance their own interests and secure legitimacy in order to remain in power.

During the late colonial period, in the face of a communist-led insurgency in the early and mid-1950s, the British colonial government initiated social reforms, including rural development efforts to consolidate a Malay yeoman peasantry, protect labour and allow limited popular political participation through elections. In the first dozen or so years after independence in 1957, largely laissez-faire policies were pursued by the first Prime Minister Tunku Abdul Rahman. These were complemented by 'mild' import substituting industrialization, some agricultural diversification, greater rural development efforts and modest, but increasing ethnic affirmative action policies.

The next dozen years saw growing state intervention under the second and third Prime Ministers, Razak Hussein (1970-6) and Hussein Onn (1976-81). The NEP provided the legitimization for increasing state intervention and public sector expansion, especially for inter-ethnic redistribution. Meanwhile, export-oriented industrialization from the late 1960s succeeded in reducing unemployment, while increased petroleum revenues financed rapidly growing public expenditure.

The heavy industrialization push began under the leadership of Malaysia's fourth Prime Minister Mahathir Mohamad during the early and mid-1980s. Counter-cyclical expansionary public expenditure expansion from 1980 was followed by budget cuts from mid-1982, but government-sponsored joint ventures with Japanese firms to develop heavy industries — constituting a second round of import substitution — grew in the face of declining foreign investments. The economic slowdown and other difficulties of the mid-1980s led to some economic and cultural liberalization. Massive ringgit depreciation from the mid-1980s was accompanied by privatization, greater official support for the private sector, increased investment incentives and regressive 'supply side oriented' tax reforms.

Significant relocation of manufacturing investments from Japan and the other firstgeneration newly industrialized East Asian economies resulted in a decade of sustained growth and rapid industrialization in Malaysia and its immediate neighbours. These policies were reversed by the regional economic crisis in 1997-8 which led to increased government intervention, especially to protect politically influential Malaysian business interests.

The preceding review of Malaysia's five distinct periods of development policy since independence has also suggested that policy changes followed political changes, especially the political crisis culminating in the events of May 1969. During Mahathir's long tenure from 1981 onwards, policy changes were driven by economic crises-in 1981-2, 1985-6 and 1997-8. With the benefit of hindsight, it is clear that new policies responded to apparent problems and failures of earlier policies. Officially, however, these transitions were often presented as obvious transitions, involving inevitable or natural progressions. This impression has been reinforced by the political longevity of the ruling coalition, which has held on to political power at the crucial central or federal level since 1955, when the first general elections were held in anticipation of imminent independence in 1957. 
All five periods considered here are discussed in nuanced and therefore chequered terms, with no unqualified successes or failures. Each set of policy innovations responded, albeit in flawed ways, to problems and challenges emerging in earlier times. The stimuli were often political, rather than economic, or perhaps more correctly, they were usually the political and cultural expressions of developmental, economic and social shortcomings. Infrastructure provision was a common feature of all five phases, albeit in very different ways and always in combination with other policy initiatives and institutional innovations.

Hence, prior conditions have always been important, but not in a deterministic way. Rather, policy interventions invariably sought to overcome constraints and difficulties inherited from the past. But, of course, options and choices were not unlimited, but very much constrained by available human, natural, financial, external and other resources. Over time, some of these resources could be increased and transformed into other types of resources to some extent. For example, natural resources can be more or less efficiently transformed into financial resources, but other factors determine how effectively such resources are invested and deployed for economic development (Khan and Jomo 2000).

The preceding review does not provide an easy formula for developmental success. The analysis has emphasized the political economy of policy-making and institutional change, but this does not mean that path dependence 'over-determines' economic development, and that there is a single explanation for success or failure. Malaysia was among the 'early birds' in developing export processing zones, but with China's emergence as the 'manufacturing workshop' of the world, this is less of a real option for most other developing countries for 'fallacy of composition' reasons. Also, little was gained by Malaysia from being an early bird in privatization or stock market promotion.

The main advantage of a 'latecomer' is the ability to learn from earlier experiences. Unfortunately, Malaysia did not learn much from the North East Asian success with effective protection conditional on export promotion-combining import substitution with export orientation - or even heavy industrialization. And while it has made impressive gains with its affirmative action policies, it is hardly a model for emulation in terms of efficient or well targeted policies, let alone improved inter-ethnic relations, or even sustained social policy gains.

With its relatively high per capita income compared to other developing countries and sustained growth over the decades, Malaysia did not need significant foreign capital to augment domestic private or public financial resources. Nevertheless, Malaysia continued to receive financial aid from abroad until the 1980s, although the nature of this assistance changed significantly over time.

FDI has long been sought, although priorities have changed over time. Many believe such FDI has been encouraged to offset primarily ethnic Chinese domestic private investment. However, besides capital, FDI has also brought access to technology, markets and relevant managerial expertise.

Some recent literature has claimed that trade liberalization or trade openness has been good for growth and development. Much of this literature has been challenged on theoretical and methodological grounds. Malaysia has undoubtedly grown more than most other developing countries, with much of the growth involving exports, initially of 
tin, then rubber and other primary commodities, most notably palm oil, wood and petroleum.

The earliest manufacturing industries involved processing primary commodities (e.g. natural rubber, tin). From the 1970s, assembly of intermediate imports and product testing became more important. The modest Malaysian value addition to these considerable imports has meant that gross trade or openness measures greatly exaggerate such growth unlike domestic resource processing, where export values reflect the full value added. Clearly, such aggregate measures offer little useful guidance to successful development policies or strategies.

Malaysia's varied and variegated experiences may offer some useful, but nevertheless complex and context-specific lessons for other developing countries at this time. The last two or three decades have seen very considerable economic liberalization on many fronts which imply very different conditions and constraints. Many of the poorest countries have been exempted from some of the trade and trade-related liberalization commitments associated with the World Trade Organization. But as many of them are heavily indebted, and therefore subject to conditionalities imposed by the Bretton Woods institutions, they are otherwise constrained besides facing various human, natural, financial and other resource constraints.

In pursuing a development strategy making effective use of available resources, developing countries today are greatly limited by the requirements of trade openness further trade liberalization in their options for developing new productive capacities and capabilities. Regaining trade policy space is thus crucial. Without appropriate trade and other economic policy interventions, it will be difficult to create the necessary conditions for kick-starting development as well as creating and enhancing the needed new production capacities and capabilities.

Incentives are needed to induce the needed investments and learning for rapid technical progress. Such inducements were needed for primary, as well as secondary and tertiary economic activities. Development and employment generation require such industrial and advanced service activities. Private agents are unlikely to undertake the needed initiatives and activities without state interventions to create the inducements for needed activities. Fiscal resources are also needed to provide the necessary infrastructure as well as other long term investments needed for development, but unlikely to be provided by private agents.

\section{Policy lessons}

It is difficult to evaluate policy success or failure simply in terms of subsequent economic performance. Malaysia's very open economy has often been subject to circumstances not of its own choosing or making.

The decline of rubber prices in the 1960s must surely have affected economic performance and policy. Malaysia's experiment with import substituting industrialization under foreign (principally British) auspices was quite different from most other developing countries' experiences where state-owned enterprises played leading roles, as well as North East Asian ones where effective protection was conditional on export promotion. Malaysia's transformation from net oil importer to 
exporter in the mid-1970s, when petroleum prices rose sharply, gave the government much more fiscal leeway, while the recycling of petrodollars later allowed it to borrow from abroad at low cost. This favourable environment lasted until the Volcker intervention of 1980 raised real interest rates and precipitated a global recession, bringing down commodity prices.

Malaysia was again favoured by international circumstances when the Plaza Accord of September 1985 led to the strong yen just as Malaysia's sovereign foreign debt became yen-denominated. But then, the mid-1980s' recession precipitated a banking crisis, which led to the 1989 banking reform. Following the apparent success of earlier deregulation, this facilitated financial liberalization, which culminated in the 1997-8 crisis. The late 1980s' regulatory reforms had encouraged further limited private foreign borrowings from abroad, limiting vulnerability on that front. The East Asian economic recovery after the last quarter of 1998, following the Russian and LTCM crises, similarly does not allow for an evaluation of the impact of Mahathir's controversial measures of early September as he moved to politically eliminate his deputy Anwar Ibrahim.

The very different economic policies pursued over the last half century as well as the often crucial role of exogenous circumstances makes an evaluation of 'the' Malaysian economic development strategy very complicated. Malaysia is considered successful because of its generally rapid rates of economic growth and structural transformation over this period. These achievements are often attributed by the Washington-based Bretton Woods institutions to its exceptionally open economy, in terms of trade and reliance on FDI, relatively low inflation, management of resource wealth and the political stability of its multiethnic society.

In such approving accounts, two periods tend to be emphasized-the 1970s, which are associated with export-oriented industrialization and the second Mahathir period, i.e. the decade from 1988 to 1997, when there was a return to such export-oriented industrialization. Other aspects of these periods are mentioned less frequently, e.g. the huge growth of state intervention and the public sector in the 1970s or Mahathir's other more heterodox policies. The import substituting industrialization of the 1960s and early 1980s are seen as mistakes overcome by subsequent policies, while most government roles beyond macroeconomic management, infrastructure as well as basic social provisioning and maintaining law and order are considered to be undermining good governance and encouraging debilitating rent-seeking.

However, a more heterodox view would underscore the role and impact of various widespread policy interventions. While some such interventions may be viewed as addressing market failures, other interventions cannot be justified in such terms, but were nonetheless crucial to Malaysia's developmental success. The main problem, often recognized by Malaysian authorities, seems to be that development is not an automatic outcome of market processes. Hence, the criterion of market failure is hardly an adequate criterion to determine interventions required to achieve economic development. This is not to suggest that all policy interventions in Malaysia have been developmental, or even intended to promote economic development. And some of those meant to be developmental have been poorly conceived or badly implemented, or abused by politically influential business interests, or otherwise proven inappropriate. Others, e.g. instances of privatization in Malaysia, were ideologically-driven, but also captured for self-aggrandizement by the politically well connected. 
The growing dominance of UMNO in the ruling coalition has meant that inter-ethnic redistribution, particularly to benefit politically connected business interests, has been the major underlying theme of much policy reform over the years. But the regime's electoral longevity has not only relied on the advantages of long term incumbency, superior financial resources, a virtual media monopoly as well as an effectively controlled electoral system, but has also depended on its ability to deliver sustained economic growth, 'law and order', as well as some basic infrastructure and social provisioning. Malaysia has also been successful in leading in the production and even the processing of several primary commodities such as tin, rubber, palm oil, timber and cocoa, while its state-owned petroleum company has been better managed than many others in developing countries. It was also a leader in producing several electronics components and other manufactured products such as air-conditioners, airplane tyres and rubber gloves, though it now appears to have lost its lead in many of these, particularly with the rise of China as the manufacturing workshop of the world. Moreover, Mahathir's car, steel and multimedia software initiatives appear to have been less than successful.

But government involvement goes back to colonial rule. Owing to its economic significance for the British empire, Peninsular Malaysia's infrastructure was quite well developed during the colonial period, while post-colonial infrastructure developments have continued to support economic development. During the colonial period, the British colonial power minimized export taxes on tin and rubber, then dominated by British corporate interests. Instead, ('sin') taxes on opium, alcohol, gambling and prostitution figured much more prominently before the Second World War, especially in the Straits Settlements ports under direct British control. British Malaya's export earnings were the main source of foreign exchange for the Empire and British reconstruction after the Second World War. Imperial preference meant fewer taxes on Malayan imports from Britain compared to those from countries outside the Empire, and this continued for a time after independence as Commonwealth preference.

Malaysia is often cited as an example of an open economy which has successfully achieved economic development. It is then suggested that trade liberalization and policies favouring FDI will lead to comparable growth and development. A more nuanced understanding of what actually happened in Malaysia suggests a more complex experience with different policy lessons. The preceding survey has highlighted how policies changed, why they changed as well as their outcomes or consequences. This has highlighted the domestic as well as international conditions prevailing. Most of Peninsular Malaysia's arable land was under cultivation by the 1980s while the debate on the remaining scope for agricultural expansion in the Borneo states of Sabah and Sarawak continues. Perhaps more importantly, Malaysian agriculture only remains viable due to the continued availability of poorly remunerated immigrant labour since the 1980s, especially from Indonesia and the Indian subcontinent.

After independence, tariffs were imposed on some imports to favour the new import substituting industries being promoted by the government in the early 1960s and early 1980s. Meanwhile, taxes on smallholders were reduced to secure their electoral support. From the early 1970s, the Free Trade Zones Act enabled the establishment of customsexempt export processing zones as well as light manufacturing warehouses to promote export-oriented industrialization. These were augmented by the provision of infrastructure and other indirect subsidies as well as labour and training policies. 
Various investment promotion policies over the decades have sought to encourage investments in particular sectors and industries. The privileged role of foreign investments in post-colonial Malaysia can be traced to the bargain made with the Malayan elite before independence in the face of a communist-led radical nationalist insurgency which threatened to nationalize British corporate interests. FDI was also encouraged to offset the ubiquitous Chinese business presence and its likely ascendance after independence and to secure advanced technology, access to foreign markets and foreign corporate expertise. Some investment regulations (e.g. the 1975 Industrial Coordination Act) and other constraints on ethnic Chinese capital accumulation may well have prevented a greater role for Malaysian entrepreneurship and corporate expansion comparable to Japan, Korea and Taiwan, Province of China.

To equate such measures with an economy open to trade and FDI obfuscates the crucial role of selective interventions to promote certain investments and technology upgrading. The decline of such efforts in the last half decade since Mahathir's retirement except for the government's agricultural promotion initiatives have been associated with more modest growth at a time when many other developing countries have actually accelerated economic growth with higher primary commodity prices due to higher demand as well as low interest rates due to US Federal Reserve Bank interventions. More of the same policies are probably inadequate in the face of the changed world economic situation.

Rather, more sophisticated, consistent and pragmatic investment and technology policies will probably need to be sustained for some time to pave the conditions for a new phase of economic development cognizant of existing problems and weaknesses, as well as strengths and potential. Unfortunately, the continuing preoccupation with interethnic distributional issues and the continuing ideological denial of the role of industrial policy in Malaysian economic development may make an informed public debate in Malaysia over such development policies difficult.

Malaysia is often touted as an example of a fast-growing NIE which has successfully achieved economic development through timely economic liberalization. However, this paper has shown that a balanced and nuanced consideration of Malaysia's experience of economic development offers lessons for other countries regarding active government involvement. But drawing lessons should not be an exercise in mechanical reproduction or emulation of specific policies or past best practices ignoring historical conditions and specific context. Experimentalism-with efforts to identify and overcome 'constraints' - may be promising, but needs to be grounded in creative and innovative ways of thinking 'outside the box' and identifying appropriate developmental policy initiatives. Some of the resulting policy options may be based on the successful Malaysian experiences of government intervention as well as critical lessons from failed experiences.

\section{References}

Jomo K. S. (ed.) (1995). Privatizing Malaysia: Rents, Rhetoric, Realities. Boulder, CO: Westview Press.

Jomo K. S. (ed.) (2002). Ugly Malaysians? - South-South Investments Abused. Durban: Institute for Black Research. 
Jomo K. S. (ed.) (2004). After The Storm: Crisis, Recovery and Sustaining Development in East Asia. Singapore: Singapore University Press.

Jomo K. S. (2007a). 'Financial Liberalisation, Crises and the Role of Capital Controls: The Malaysian Case'. Economic and Political Weekly XLII (50), Dec. 15-21: 73-8.

Jomo K. S. (ed.) (2007b). Malaysian Industrial Policy. Singapore: Singapore University Press, and Honolulu: University of Hawaii Press.

Jomo K. S. with Wong Sau Ngan (eds) (2008). Law, Institutions and Malaysian Economic Development. Singapore: National University of Singapore Press.

Jomo K. S., Chang Y. T., Khoo K. J. with others (2004). Deforesting Malaysia: The Political Economy and Social Ecology of Agricultural Expansion and Commercial Logging. London: Zed Books.

Khan, Mushtaq, and Jomo K. S. (eds) (2000). Rents, Rent-Seeking and Economic Development: Theory and the Asian Evidence. Cambridge: Cambridge University Press.

Tan Tat Wai (1982). Income Distribution and Determination in West Malaysia. Kuala Lumpur: Oxford University Press.

Wong Sook Ching and Jomo K. S. with Chin Kok Fay (2005). Malaysian 'Bail-Outs'? Capital Controls, Restructuring and Recovery in Malaysia. Singapore: Singapore University Press.

World Bank (1983). Malaysia: Structural Change and Stabilization. Washington, DC: World Bank. 